\title{
AN ASSESSMENT OF WIND FARM CONSTRUCTION EFFICIENCY \\ USING THE REAL OPTION METHOD
}

Tomasz Łukaszewski, Ph.D.

University of Szczecin

Faculty of Economics and Management

Institute of IT in Management

Mickiewicza 64, 71-101 Szczecin, Poland

e-mail:tomasz.lukaszewski@wneiz.pl

Wojciech Głoćko, MSc

Chairman of the Board

Epa Wind sp. z o.o

Wojska Polskiego 156, 71-324 Szczecin, Poland

e-mail:w.glocko@epawind.pl

Received 29 January 2016, Accepted 16 November 2016

\begin{abstract}
From a developer's point of view the construction of a wind farm in Poland is an investment project assessed in terms of economic efficiency. This paper discusses the selection of methods to be used for the assessment of such investments: it proposes to consider wind farm construction as an option and price it using models developed for the financial market. The purpose of the paper is to present a practical application of the option pricing method to the assessment of wind farm construction efficiency, in particular to compare the option and discount methods. Calculations are based with the example of an actual wind farm completed by one of the authors. The values of the project are different depending on the chosen method of estimation. The pricing carried out using the options method will lend legitimacy to the DCF result or suggest the verification of its correctness and review of the assumptions made. In both cases the application of the options method will have an advantageous impact on the investment decision.
\end{abstract}

Keywords: real options, efficiency assessment, wind farms

JEL classification: G13, G31, Q42 


\section{Introduction}

A wind farm is construed as a single or group of generating units (turbines) using wind energy to produce electricity, connected to the electricity grid in a single point of connection. The construction of a wind farm is a complex investment project which, pursuant to the rational economy principles, shall be subject to economic calculation. Investment efficiency assessment usually uses methods based on discounted cash flow, such as NPV, IRR and their derivatives. It is proposed to use other measures, including real options, in circumstances where the applicability of discounting methods is limited. The real option method assumes certain analogies between the implementation of an investment project and the purchase of options on the financial market, allowing for pricing real investments using financial market instruments (Copeland, Antikarov, 2001).

This paper assesses the efficiency of an investment consisting of the construction of a $20 \mathrm{MW}$ wind farm. It was assumed that investment work would last 4 years starting in 2009 and would require the financial expenditure of PLN 134 million. Production and sale of electricity was due to commence in 2013, and would be carried out for a period of 20 years and yield PLN 157 million in revenue over that period. The project was associated with specific and market risks. Specific risks pertain to the course of investment work, whereas market risks pertain to potential changes to energy prices. The economic efficiency of the investment was first assessed using the DFC method, followed by the real option method. The results were compared and analysed.

\section{Wind farm construction as an investment process}

\subsection{The wind farm investment process}

The wind farm investment process may be divided into three key stages (Bęben, Chmielewski, 2012):

- development and design work,

- construction and installation work,

- operation.

Development and design work are usually carried out by developer companies. The companies perform an initial screening of a selected site in terms of the possibility to build a wind farm. Subject to assessment are factors such as land availability for the construction of the wind farm, the type and topography of the land, condition of access roads, existing or 
potential power grid connection points, wind conditions as well as legal, environmental, social and technical determinants. The screening results are included in a site report. If all preliminary opinions are positive, a schedule of work is developed and the project budget is then established. In case of negative conclusions from the screening the project is cancelled.

Design work consists in the performance of all actions aimed at the acquisition of permits, approvals and consents as required by law and at the conclusion of agreements enabling the commencement of the construction work and, after its completion, the operation of the wind farm. Wind farm design work may be divided into the following stages:

1. Stage I - Acquisition of an environmental decision.

2. Stage II - Acquisition of grid connection conditions and wind measurement results.

3. Stage III - Acquisition of a building permit.

Stage I includes work related to wind measurements, the launch of administrative procedures (adoption of a land use plan and a local spatial development plan) and the environmental impact assessment procedure. The latter includes bird and bat monitoring and the development of an environmental impact assessment report. A positive environmental impact assessment constitutes a rationale for the continuation of the work, whereas negative - for the abandonment of the project. In Figure 1 the commencement of Stage I has been marked as 0, whereas its end as $t_{1}$. Stage II includes work related to the development, filing and examination by a grid operation of an application for the connection of the wind farm to the power grid as well as wind measurements and the development of a project profitability assessment. Insufficient wind conditions entail abandonment of the project due to its economic unprofitability. Stage II is concluded with the acquisition of grid connection conditions $\left(t_{2}\right)$. A refusal to issue the connection conditions constitutes a basis for resignation from the project. Stage III includes a further administrative procedure and is concluded with the acquisition of a building permit for the wind farm $\left(t_{3}\right)$. Its acquisition ends the design work.

The design and development work takes a reasonable amount of time; in Poland this is usually 3 to 7 years. In the analysed project Stage I lasted 18 months, Stage II 6 months, whereas Stage III lasted 12 months. The risk related to each stage is high; the lack of any key document precludes the possibility to build a wind farm in a selected location. The value of funds employed at that stage is relatively insignificant compared to all funds necessary to build a wind farm (usually not exceeding 5-10\% of the total cost); however they are subject to a significant loss risk. Design work is concluded upon the acquisition of a final building permit for the wind farm.

The construction stage consists in the performance of work related to the construction of the wind farm and its connection to the power grid. The stage ends with the commissioning 
of the wind farm. The commissioning concludes the construction and commences the operation stage. Construction is reasonably short (12 months in the analysed case), but requires substantial expenditure, up to $95 \%$ of the total investment cost (Pesta, 2009). In 2013 the estimated value of expenditure amounted to approximately PLN 6 million per $1 \mathrm{MW}$ of wind farm capacity; assuming that the average rated capacity of a single turbine ranges from 2.0 to $3.2 \mathrm{MW}$ this entails turbine construction costs at a level of PLN 12-20 million. To calculate investment expenditures for a wind farm one shall multiply the amount by the number of installed turbines. The implementation of such a capital-intensive investment requires long-term bank credit financing.

The operation stage commences after the construction and installation work is complete. Operation of a wind farm consists in the production of electricity. The owner's revenues include proceeds on the sale of electricity and certificates of origin (green certificates) confirming the production of electricity from renewable sources. The revenues are decreased by the operating costs.

The model of wind farm investment is presented in Figure 1.

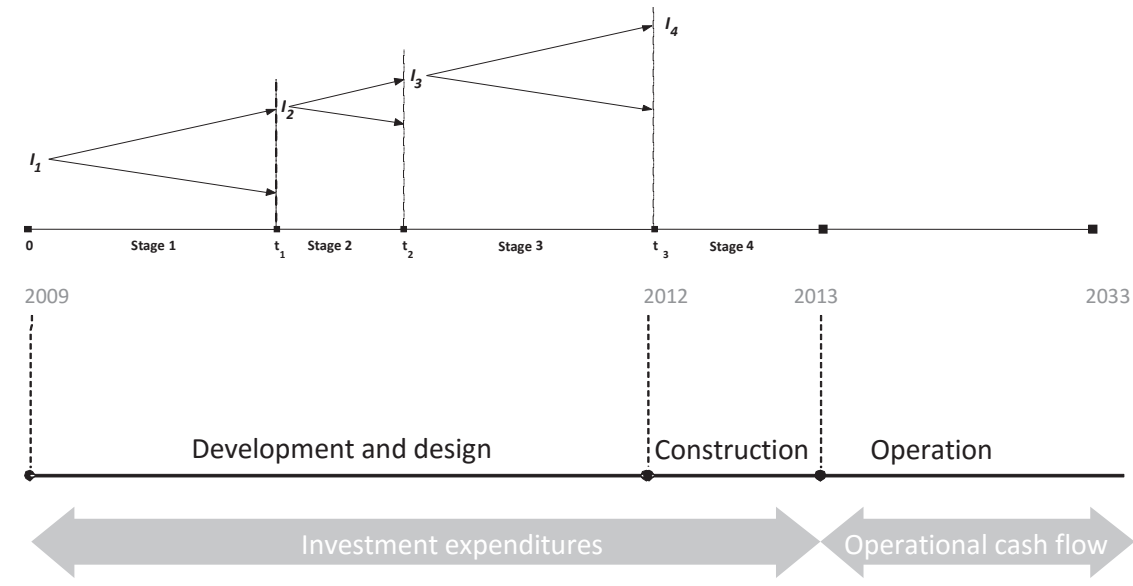

Figure 1. Options in wind farm construction

Source: own work.

\subsection{Project investment expenditures}

The construction of a wind farm is a capital-intensive project, requiring financial expenditure, whose value primarily depends on the planned capacity of the wind farm. This is caused by the dominant effect of turbine purchase costs. Because there is a relationship between 
expenditures on a wind farm and its capacity, it seems more proper to specify costs per unit of wind farm capacity.

Expenditures related to the construction of a wind farm have been allocated to particular project stages and accordingly marked. The presented expenditures apply to a wind farm with a capacity of 20 to $40 \mathrm{MW}$.

Table 1. Investment expenditures on the construction of a wind farm

\begin{tabular}{|c|c|c|c|}
\hline Stage & Designation & Category & $\begin{array}{l}\text { PLN/MW } \\
\text { (PLN) }\end{array}$ \\
\hline \multirow{5}{*}{$\begin{array}{l}\text { SStage I. Acquisition } \\
\text { of an environmental } \\
\text { decision }\end{array}$} & \multirow{5}{*}{$\mathrm{I}_{1}$} & Wind measurements & 20,000 \\
\hline & & $\begin{array}{l}\text { Adoption of a land use plan and a local spatial } \\
\text { development plan }\end{array}$ & 20,000 \\
\hline & & Bird and bat monitoring & 15,000 \\
\hline & & $\begin{array}{l}\text { Development of an environmental impact assessment } \\
\text { report for the wind farm }\end{array}$ & 15,000 \\
\hline & & Total & 70,000 \\
\hline \multirow{3}{*}{$\begin{array}{l}\text { Stage II. Acquisition } \\
\text { of grid connection } \\
\text { conditions and wind } \\
\text { measurement results }\end{array}$} & \multirow{3}{*}{$\mathrm{I}_{2}$} & $\begin{array}{l}\text { Development and submission of an application } \\
\text { for the connection of a wind farm to the grid }\end{array}$ & 10,000 \\
\hline & & Wind measurements & 40,000 \\
\hline & & Total & 50,000 \\
\hline \multirow{2}{*}{$\begin{array}{l}\text { Stage III. Acquisition } \\
\text { of a building permit }\end{array}$} & \multirow{2}{*}{$\mathrm{I}_{3}$} & Acquisition of a building permit for a wind farm & 80,000 \\
\hline & & Total & 80,000 \\
\hline \multirow{6}{*}{$\begin{array}{l}\text { Stage IV. Performance } \\
\text { of construction and } \\
\text { installation works }\end{array}$} & \multirow{6}{*}{$\mathrm{I}_{4}$} & Acquisition of a building permit for a wind farm & 80,000 \\
\hline & & Securing project financing & 20,000 \\
\hline & & $\begin{array}{l}\text { Development of road infrastructure, earthwork } \\
\text { and foundation work }\end{array}$ & 600,000 \\
\hline & & Connection of a wind farm to the grid & 400,000 \\
\hline & & Purchase and installation of wind turbines & $5,400,000$ \\
\hline & & Total & $6,500,000$ \\
\hline \multicolumn{3}{|c|}{ Total wind farm construction cost in PLN per MW } & $6,700,000$ \\
\hline
\end{tabular}

Source: own work.

Investment expenditures in the analysed project were estimated on the basis of the data presented in Table 1. To specify their current value a risk-free interest rate of $r_{f}=4.5 \%$ as well as the specified duration of particular stages was used. The calculations assume that investment expenditures incurred during each stage are discounted to the start of the period. Total expenditures in the project amounted to PLN 134 million, which after discounting to the year 2009 amounted to PLN 117,719,834. Discount calculations are presented in Table 2. 
Table 2. List of expenditures in the analysed wind farm project

\begin{tabular}{|l|c|c|c|c|c|}
\hline \multirow{2}{*}{\multicolumn{2}{|c|}{ Stage }} & \multicolumn{5}{|c|}{ Project investment expenditures } \\
\cline { 3 - 6 } \multicolumn{2}{|c|}{} & $\begin{array}{c}\text { expenditures/MW } \\
\text { (PLN/MW) }\end{array}$ & $\begin{array}{c}\text { stage expenditures } \\
(\text { PNL) }\end{array}$ & $\mathrm{t}$ & $\begin{array}{c}\text { discounted expenditures } \\
\text { (PLN) }\end{array}$ \\
\hline Stage I & $\mathrm{I}_{1}$ & 70,000 & $1,400,000$ & 0 & $1,400,000$ \\
\hline Stage II & $\mathrm{I}_{2}$ & 50,000 & $1,000,000$ & 1.5 & 936,107 \\
\hline Stage III & $\mathrm{I}_{3}$ & 80,000 & $1,600,000$ & 2 & $1,465,168$ \\
\hline Stage IV & $\mathrm{I}_{4}$ & $6,500,000$ & $130,000,000$ & 3 & $113,918,559$ \\
\hline Total & & $134,000,000$ & & $117,719,834$ \\
\hline
\end{tabular}

Source: own work.

\subsection{Wind farm operating cash flow}

A wind farm gains revenues from the sale of electricity and certificates of origin. In accordance with the Energy Law an operator shall be obligated to purchase the entire electricity produced from renewable energy sources at the average electricity sale price in the previous calendar year (TPA Horwath, PAIiIZ, BSJP law firm, 2012). Certificates of origin, constituting an element of a renewable energy support scheme, are confirmation that the electricity sold has been produced from a renewable source. For each produced unit of green electricity the producer receives a certificate, constituting proprietary interest. A certificate is subject to trading on the Polish Power Exchange (PolPX). The price of the certificates of origin are developed through the balance between demand and supply.

The project assumed that the operation stage when the wind farm generates positive cash flow lasts 20 years. Revenues in that period are subject to market risk, whose components include variations in electricity prices and modifications to the support scheme for renewable energy producers. Due to the long-time perspective of the investment such changes are difficult to forecast. An investment decision concerning the implementation of the analysed investment was to be made at the beginning of 2009. It was assumed for calculations that the production and sale of electricity would commence in 2013 and would be carried out for a period of 20 years. The market price of electricity was specified at PLN 194 per MWh (equivalent to the average electricity price in the previous year), whereas the price of certificates of origin at 276 PLN/ MWh. Additional assumptions made in the model are presented in Table 3. 
Table 3. Assumptions to the determination of project cash flow

\begin{tabular}{|l|c|l|c|}
\hline \multicolumn{4}{|c|}{ Assumptions to the determination of project cash flow } \\
\hline Wind farm capacity (MW) & 20 & Loan interest rate (\%) & 7.00 \\
\hline Turbine productivity (MWh) & 2,800 & WACC (\%) & 6.84 \\
\hline Yearly production (MWh) & 56,000 & Risk-free rate (\%) & 4.50 \\
\hline Operating costs share (\%) & 20 & Loan term & 10 \\
\hline Equity share (\%) & 20.00 & Depreciation rate (\%) & 10.00 \\
\hline Borrowed capital share (\%) & 80.00 & Tax rate (\%) & 19.00 \\
\hline Equity cost (\%) & 11.50 & Inflation rate (\%) & 2.00 \\
\hline
\end{tabular}

Source: own work.

On the basis of the data presented above it was estimated that the expected net value of cash flow in the 2013-2033 period will amount to PLN 155.5 million. After discounting the amount at the start of year 2009 using capital cost (WACC $=6.84 \%$ ) the cash flow amounts to PLN 119.4 million.

\subsection{Assessment of wind farm construction efficiency using the discount method}

To determine the value of an investment project using the NPV method one shall discount all cash flows using the appropriate discount rate at the beginning of the period and then add them up (Rogowski, 2004). The value of the analysed project amounts to:

$$
\begin{gathered}
\mathrm{NPV}=(-1,400,000)+(-936,107)+(-1,465,168)+ \\
+(-113,918,559)+119,416,087=1,696,253 .
\end{gathered}
$$

A positive result denotes economic profitability of the investment and constitutes a rationale for a decision to implement it. However, when assessing wind farm construction efficiency one has to consider the potential project termination after each stage if the scheduled milestones are not achieved. To correct the result the probability of success of particular stages was estimated on the basis of expert knowledge. The probability of success of particular stages is as follows:

- Stage I $P_{1}=50 \%$,

- Stage II $P_{2}=50 \%$,

- Stage III $P_{3}=80 \%$,

- Stage IV $P_{4}=100 \%$.

The above enabled the specification of weights for probabilities that particular cash flows will be achieved. The Expected Net Present Value (ENPV) of the project, taking account of the specific risk, is as follows: 


$$
\begin{gathered}
\text { ENPV }=(-1,400,000)+50 \% \times(-936,107)+25 \% \times(-1,465,168)+ \\
+20 \% \times(-113,918,559)+20 \% \times 119,416,087=-1,134,840 .
\end{gathered}
$$

Negative result indicates that the project shall be rejected.

Economic efficiency of the wind farm construction estimated by the NPV method amounts to PLN 1.7 million, however it falls to (PLN -1.1 million) if a specific risk is considered. This means that project implementation is unprofitable due to the specific risk of the investment process. However, the result does not reflect the actual value of the investment, which, if successful, will yield approximately PLN 1.7 million of profit, whereas in the case of a failure will entail a loss of up to PLN 4 million (depending on the stage the project is cancelled at). Project value calculated in accordance with the ENPV method constitutes the sum of discounted cash flows corrected with an arbitrarily assumed probability of success of the particular stages. Neither the NPV or ENPV method allow for the correct assessment of economic efficiency of a project which may be abandoned at a certain intermediate stage. Therefore, it is concluded that discounted cash flow (DCF) based methods are not well suited to the assessment of a multistage project, such as the construction of a wind farm.

\section{Real option method in wind farm efficiency assessment}

\subsection{Identification of options within the project}

The problem faced by the developer may be expressed as follows: how to assess the efficiency of projects, whose construction takes account of the potential abandonment in case of failure of a certain stage? The authors propose to use the Real Options Method to solve the problem.

The application of the option method for the evaluation of real investment has been examined in the literature since the 1990's by Dixit and Pindyek (1994), Trigeorgis (1996), Copeland and Antikarov (2001) and others. Among Polish researchers studying this issue are Ziarkowski (2004), Mizerka (2005), Wiśniewski (2008). Research on employing the real options approach in the field of renewable energy were undertaken i.e. by Mendez, Goyanes and Lamothe (2009) and Frolund and Obling (2010).

The method assumes certain analogies between the implementation of an investment project divided into stages and the purchase of options on the financial market. In accordance therewith the investor commencing the first stage of the project gains the opportunity (purchases an option) to implement subsequent stages and gain benefits, similarly to an investor purchasing 
an option on the financial market gaining the opportunity to buy (or sell) the underlying commodity, which the option pertains to, at an advantageous price (Dixit, Pindyck, 1994) In accordance with the presented perspective a real option shall be considered as the right of the subject implementing the investment project to acquire future cash flows associated with the project. The right applies until the expiry of the investment opportunity (Trigeorgis, 1996). The application of the options method enables the inclusion of additional value stemming from active management of a stage-based investment project in the efficiency calculation. An option has a value only when the following two conditions are simultaneously met:

- there exists uncertainty as to the value of the cash flows expected in the project, and

- the investor may limit the uncertainty by taking certain action, which is referred to as managerial flexibility.

The real options approach is a method to describe and quantify the value stemming from the active management of the investment process. It enables quantitative flexibility measurement by considering it as an option issued on real assets and prices using methods appropriate for financial options (Łukaszewski, 2010).

\subsection{Development of a real option pricing model}

The value of a financial option $C$ is the function of six variables:

$$
C=f\left(S, X, \sigma, t, r_{f}, \rho\right)
$$

where:

$S$ - price of underlying asset,

$X$ - strike price,

$\sigma-$ price variability of underlying asset,

$t$ - option term,

$r_{f}$ - risk-free interest rate,

$\rho-$ dividend during the option's term.

The analogy between the situation of an investor considering taking certain economic action and the situation of a financial option holder is used to specify the variables of the real option model. Relevant elements of the investment calculation are attributed to factors determining the value of a financial option. Variable pairs are listed and described below. 
Table 4. Investment expenditures on the construction of a wind farm

\begin{tabular}{|l|l|c|}
\hline \multicolumn{1}{|c|}{ Financial options } & \multicolumn{1}{c|}{ Real options } & Variable \\
\hline Value of the option & Value of investment opportunity & $\mathrm{C}$ \\
\hline Price of underlying asset & Net present value of benefits from the investment project & $\mathrm{S}$ \\
\hline Strike price & Investment expenditures or benefits from alternative use of assets & $\mathrm{I}$ \\
\hline Price variability of underlying asset & Uncertainty concerning future cash flow & $\sigma$ \\
\hline Option term & Time to make a decision regarding the project & $\mathrm{t}$ \\
\hline Risk-free interest rate & Time value of money & $\mathrm{r}_{\mathrm{f}}$ \\
\hline Lost dividend & Lost cash flow & $\rho$ \\
\hline
\end{tabular}

Source: own work.

In the real option valuation method the price of underlying asset is the net value of cash flow of the investment project. The analogy is not full due to the differences between financial and real assets. By purchasing a financial option the holder receives an instrument (such as stock, currency or indices), whose value is developed by the market, whereas by exercising a real option an investor gains capital assets, whose value results from the capacity to generate cash flow. Real assets are not subject to free trading, hence their price is not specified by the market (Trigeorgis, 1996). The above difference breaches the market completeness assumption, on which the financial option pricing method is based. Therefore, it is required to assume the existence of a twin security, whose changes in value are perfectly correlated with the changes in the value of the asset, which is covered by the real option. In accordance with the MAD (Market Asset Disclaimer) concept the twin security role may be played by the net value of the project's cash flow, being the best estimate of the value that the project would have, had it been subject to market trading (Copeland, Antikarov, 2001).

The strike price of a financial option is reflected by the value of investment expenditures. Contrary to a financial option, where the strike price is fixed and known upon execution of a contract, in a real option the price may be known or unknown. Moreover, investment expenditures may assume the form of a series of payments spread over time, which requires aggregation thereof.

The variability parameter reflects the changes in the price of the underlying asset during the option's term. In the case of investment projects variability reflects uncertainty concerning future cash flows. The higher the variability, the more likely the final project value will be higher or lower than assumed. Variability may be affected by one or many risk factors; it is crucial to distinguish between specific risk (specific for a particular project) and systematic risk (related to factors affecting all subjects operating on the market). Specific risk reduces, whereas systematic 
risk increases the option value. The total option value depends on the relation between specific and systematic risk and requires the determination of a correlation between them.

The term of a real option is limited by the deadline for the investment decision. The option expires after the deadline. The option term may be known or unknown; furthermore, it may depend on the exercise of another option or the occurrence of a certain event.

The risk-free interest rate is present both in the financial and real option model. It is specified on the basis of the interest rates of risk-free securities, issued for a period corresponding to the option term.

Dividend in the real option model is the cost incurred by the investor upon resignation from immediate implementation of the project. It may have the form of lost revenues or a decrease in their future value as a result of actions taken by the competition. The inclusion of competition effects leads to a division of options into exclusive and common. Exclusive options may be exercised only by the holder, contrary to common options, which may also be exercised by the competition. In case of common options the waiting cost will be particularly high if the first competitor exercising the option gains a substantial market advantage. In such circumstances the dividend substantially decreases the option value.

After the adaptation of variables real options may be priced using financial option models. In the analysed example the Cox, Ross and Rubinstein binominal model will be used (Cox, Ross, Rubinstein, 1979). It is based on the assumption that the price of the underlying asset changes in subsequent periods in line with a multiplicative binominal process. This means that the asset price equal to $S$ at the beginning of a period may increase to $S_{u}$ at the end of the period with probability $q$ or decrease to $S_{d}$ with probability $(1-q)$. The increase $u$ and decrease $d$ factors represent a logarithmic rate of return accompanying the increase and decrease in the price of the asset in line with the following relation: $d=1 / u$. To avoid arbitrage the risk-free interest rate must be constant over time and comply with the following condition: $u \geq\left(1+r_{f}\right) \geq d$.

\subsection{Identification of options within the project}

In the proposed concept the commencement of the first stage of the wind farm is considered as a purchase of an option issued for the value of the second stage of the works (Frolund, Obling, 2010). By commencing the first stage and incurring related investment expenditures $I_{1}$ the investor purchases the right to continue the project and gain future benefits. After the conclusion of the first stage the investor may exercise the option, i.e. commence the next stage, or resign and end the project. Exercise of the option entails investment expenditures $I_{2}$ being the equivalent 
of the strike price. In exchange the investor acquires the right to continue the project (a second option) and related future benefits. A similar situation pertains to subsequent stages. After the end of the third stage the investor must decide on the commencement of civil and installation work (exercise of the third option). The strike price equals investment expenditures $I_{4}$, whereas the value of the underlying asset is reflected by the sum of cash flows of the wind farm operation stage. The investor will decide to commence the civil work if the value of the discounted cash flow of the operation stage is higher than the investment expenditure $I_{4}$.

Implementation of the project in question may be considered as the purchase of a complex option:

- Option $I$ is embedded in the project. The purchase cost is included in expenditures $I_{1}$ incurred to perform stage 1. Strike price of option $I$ is equal to expenditures $I_{2}$ that have to be incurred in conjunction with the performance of stage 2 . The value of the underlying asset is reflected by the present value of the project at $t_{1}$. The option will be exercised if the present project value at the exercise date will be higher than the strike price. The exercise date is specified, hence this is a European option.

- Option II will exist only if the investor decides to commence the second stage of the project. Its purchase cost is included in expenditures $I_{2}$ incurred to perform stage 2 and at the same time constitutes the strike price of option I. The strike price of option II is equal to expenditures $I_{3}$ incurred to perform stage 3. Option $I I$ will be exercised if the present project value at $t_{2}$ will be higher than strike price $I_{3}$. The exercise date is specified, hence this is a European option.

- Option III will exist only if option II is exercised, i.e. if the investor decides to commence the third stage of the project. The purchase cost is included in expenditures $I_{3}$ incurred to perform stage 3. The strike price of option III is equal to expenditures $I_{4}$ incurred on civil and installation work. Option III will be exercised if the sum of net operating cash flow discounted to option exercise date $t_{3}$ is higher than the cost of civil and installation work $I_{4}$. The exercise date is specified, hence this is a European option.

The described structure is presented in Figure 2.

By commencing a particular stage of design work the investor acquires an option (opportunity) to perform subsequent stages. Each time after the conclusion of a stage of work the investor possesses a project, whose present value is $S$ and an option to continue it, whose value may be estimated using the financial option pricing model. 


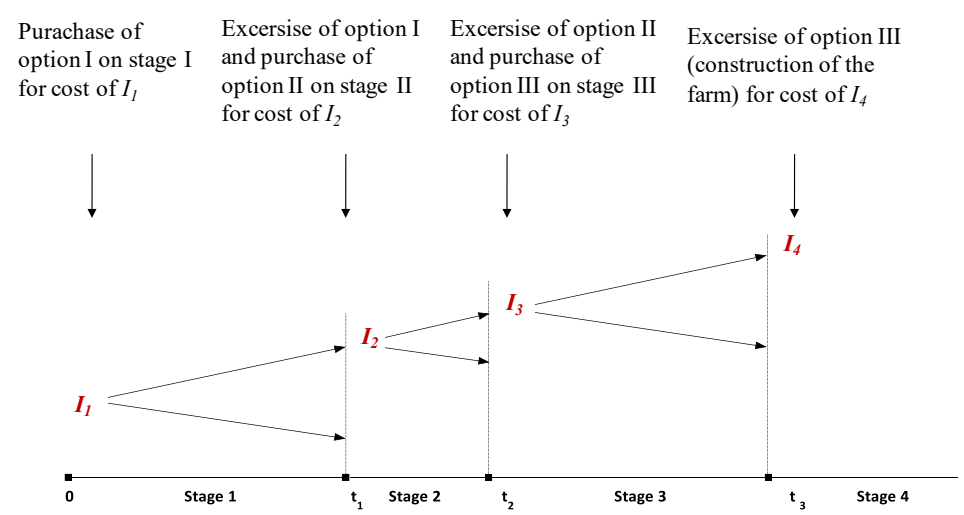

Figure 2. Options in wind farm construction

Source: own work.

\subsection{Wind farm efficiency calculation using the real option method}

The first step to determine the efficiency of a wind farm using the option method is to identify and quantify variables of the pricing model.

In accordance with the assumptions made, development work on the project would last from 2009 to 2012 and comprise three stages of different length. For pricing purposes the period was divided into 6 sub-periods (intervals) of $t=0.5$ year each. Stage I comprises 3 intervals, stage II comprises one, whereas stage III lasts 2 intervals. In each stage the binominal process is carried out as many times as there are intervals.

The sum of cash flows of the operational stage of the project $S$ discounted to the decision making time $t=0$ using WACC $=6.84 \%$ amounts to PLN $119,416,087$.

The asset price variability is reflected by changes to investment value in subsequent periods. This may be construed using the following example: expected value of the project $S$ at $t_{0}$ may upon acquisition of an environmental deadline $\left(t_{1}\right)$ increase or decrease depending on provisions of the decision. For instance, if the wind farm site is limited, the number of turbines will be decreased, and the project value will fall. If provisions of the decision do not limit the wind farm site, or if revenue calculations are made for a number of turbines below the maximum allowable number, or it became possible to use more efficient generators, the project value would rise. Similarly, in subsequent periods the impact of risk on the project would be symmetrica 1. Variability in the project was designated using the annual standard deviation of future cash flows $\sigma_{r}=20 \%$. Due to the interval assumed in the model the variability was translated into semiannual, which amounted to $\sigma=14.14 \%$. As in the binominal model variability is specified by 
increase and decrease factors $u$ and $d$ it was necessary to determine such factors in accordance with the following formula:

$$
\begin{gathered}
u=e^{\sigma \sqrt{\Delta t}}=e^{0.1414 \times \sqrt{0,5}}=1.105, \\
d=1 / u=0.905
\end{gathered}
$$

The value of the analysed project equal to $S_{0}=119,416,087$ at the beginning of the period may increase to PLN $S_{u}=S_{0} \times u=131,975,186$ or decrease to $S_{d}=S_{0} \times d=108,052,143$ at the end of the first period $(\mathrm{t}=1)$. The project value in subsequent periods until the end of development work is determined in a similar way. Values estimated using the binominal tree are presented in Table 5.

\begin{tabular}{|c|c|c|c|c|c|c|}
\hline$t=0$ & \multicolumn{3}{|c|}{ Stage I } & Stage II & \multicolumn{2}{|c|}{ Stage III } \\
\hline 2009 & I 2009 & II 2009 & I 2010 & II 2010 & I 2011 & II 2011 \\
\hline \multirow[t]{7}{*}{$119,416,087$} & $131,975,186$ & $145,855,138$ & $161,194,856$ & $178,147,867$ & $196,883,842$ & $217,590,296$ \\
\hline & $108,052,143$ & $119,416,087$ & $131,975,186$ & $145,855,138$ & $161,194,856$ & $178,147,867$ \\
\hline & & $97,769,623$ & $108,052,143$ & $119,416,087$ & $131,975,186$ & $145,855,138$ \\
\hline & & & $88,465,613$ & $97,769,623$ & $108,052,143$ & $119,416,087$ \\
\hline & & & & $80,046,997$ & $88,465,613$ & $97,769,623$ \\
\hline & & & & & $72,429,518$ & $80,046,997$ \\
\hline & & & & & & $65,536,938$ \\
\hline$I_{1}=1,400,000$ & \multicolumn{3}{|c|}{$\mathrm{I}_{2}=1,000,000$} & $\mathrm{I}_{3}=1,600,000$ & \multicolumn{2}{|c|}{$\mathrm{I}_{4}=130,000,000$} \\
\hline
\end{tabular}

Table 5. Cash flow value determined using the binominal tree

Source: own work.

As mentioned above, there are three options in the project. The pricing process should be started with the calculation of the value of the third option in its exercise date. Then, going back in steps, one determines the value of the options $C$ in the previous periods, until the initial value at $t=0$ is determined (Frolund and Obling).

The value of the third option at exercise date $(\mathrm{t}=6) C_{6}$ corresponds to the project value upon conclusion of the development work. If the sum of expected cash flows of the operating period $S$ is higher than investment expenditures $I_{4}=$ PLN 130,000,000, the investor will commence civil and installation work; otherwise the project will be cancelled. Hence, the value of the third option $C$, at the execution date equals to $\max \{(S-I) ; 0\}$. For a variant assuming that project value in subsequent periods will only increase the option price will amount to: $C_{61}=\max \left\{\left(S_{u^{6}}-I\right) ; 0\right\}=217,590,296-130,000,000=87,590,296$. If the project value increases in the first five periods and decrease in the last, the option would be worth $C_{62}=\max \left\{\left(S_{u^{5 d}}-I\right) ; 0\right\}=178,147,867-130,000,000=48,147,867$. If the project value 
increases over four periods and decreases in the last two, the option price will amount to $C_{63}=\max \left\{\left(S_{u^{4} d^{2}}-I\right) ; 0\right\}=145,855,138-130,000,000=15,855,138$. For other combinations of increases and decreases the value of project cash flow discounted at the end of 2011 is lower than investment expenditure $I_{4}$. In such a case the option value is zero and the investor would resign from building the wind farm.

A subsequent step is to value the project at $t=5$. The option price is determined as the product of option prices of the sixth period and corresponding probability of increase and decrease, discounted with a risk-free interest rate:

$$
C_{5}=\left(p \times C_{6 u}+q \times C_{6 d}\right) /\left(1+r_{f}\right) .
$$

The probability of an increase of $p$ and decrease of $q$ was determined on the basis of the following formula:

$$
\begin{gathered}
p=\frac{e^{\Delta t \times r f}-d}{u-d}=\frac{e^{0.5 \times 0.045}-0.905}{1.105-0.905}=0.5886, \\
q=1-p=0.4114
\end{gathered}
$$

The option value in case of increase in the project value would amount to:

$$
C_{51}=(0.5886 \times 87,590,296+0.4114 \times 48,147,867) /(1+0.025)=69,793,585 .
$$

The option value for variants $C_{52}=34,095,698$ and $C_{53}=9,127,079$ was determined in a similar way.

Option values for subsequent periods were determined accordingly. The results are presented in Table 6 .

Table 6. Project option value

\begin{tabular}{|c|c|c|c|c|c|c|}
\hline $\mathrm{t}=0$ & \multicolumn{3}{|c|}{ Stage I } & Stage II & \multicolumn{2}{c|}{ Stage III } \\
\hline 2009 & I 2009 & II 2009 & I 2010 & II 2010 & I 2011 & II 2011 \\
\hline $11,036,482$ & $18,720,195$ & $26,994,570$ & $37,834,491$ & $52,295,070$ & $69,793,585$ & $87,590,296$ \\
\hline & $4,806,334$ & $7,905,371$ & $12,961,601$ & $21,699,533$ & $34,095,698$ & $48,147,867$ \\
\hline & & 635,215 & $1,103,466$ & $3,654,043$ & $9,127,079$ & $15,855,138$ \\
\hline
\end{tabular}

Source: own work.

The project value calculated using the option method amounts to PLN 11.036 million. 
Analysing the result one has to consider the difference between the interpretation of financial and real options. Financial options are used to hedge the buyer from risk, whereas their pricing enables to specify the cost of such hedging, constituting "fair" remuneration for the option writer. Real options enable the assessment of investment project efficiency by determining the boundary value of its implementation cost.

In the analysed case the commencement of stage I of the project entails PLN 1.4 million of expenditures to acquire an environmental decision. Depending on environmental determinants the value of the project holding the decision ranges from PLN 37,834,491 to PLN 0. Commencing stage II of the project the investor pays PLN 1 million for wind measurement results and grid connection conditions. Depending on wind conditions and detailed connection conditions the project value may range from PLN 52,295,070 to PLN 0. The commencement of stage III of the project consisting in the acquisition of a building permit for the wind farm costs PLN 1.6 million. The analysed project holding full documentation, including the building permit, is worth from PLN 87,590,296 to PLN 0.

The decision-making problem may be formulated as follows: Is it worth to pay PLN 4 million for the capacity to build a wind farm knowing that the investment may yield income from PLN 87.6 million to 0 ? The application of the option method enabled to determine that upon decision-making the investment value is approximately PLN 11 million. As long as the cost of investment work does not increase above the amount, project implementation is financially legitimate.

The value determined by the binominal model takes account only of the systematic risk; however, the project is also related to specific risk, whose impact on the project is only adverse. The risk pertains to the investment process and consists in the acquisition of a negative environmental decision, disadvantageous wind measurement results, a grid operator's refusal to issue grid connection conditions and a failure to acquire a building permit for the wind farm. The occurrence of any of the listed factors would result in the non-achievement of the assumed stage goal and cancellation of the project. To include specific risk, option pricing would be corrected with the probability of the success of particular stages as estimated by experts. The calculations are presented in Table 7. 
Table 7. Option value in the project taking account of the specific risk

\begin{tabular}{|c|c|c|c|c|c|c|}
\hline$t=0$ & \multicolumn{3}{|c|}{ Stage I } & Stage II & \multicolumn{2}{|c|}{ Stage III } \\
\hline 2009 & I 2009 & II 2009 & I 2010 & II 2010 & I 2011 & II 2011 \\
\hline \multirow[t]{4}{*}{$1,340,296$} & $4,164,086$ & $6,023,223$ & $8,373,190$ & $23,244,986$ & $59,709,238$ & $70,072,237$ \\
\hline & $1,002,934$ & $1,731,844$ & $2,990,400$ & $10,849,766$ & $34,095,698$ & $48,147,867$ \\
\hline & & 14,890 & 25,866 & $1,827,021$ & $9,127,079$ & $15,855,138$ \\
\hline & & & & & & - \\
\hline $\mathrm{I}_{1}=1,400,000$ & \multicolumn{3}{|c|}{$\mathrm{I}_{2}=1,000,000$} & $I_{3}=1,600,000$ & \multicolumn{2}{|c|}{$\mathrm{I}_{4}=130,00,000$} \\
\hline $\mathrm{P}_{0}=100 \%$ & \multicolumn{3}{|c|}{$\mathrm{P}_{1}=50 \%$} & $\mathrm{P}_{2}=50 \%$ & \multicolumn{2}{|c|}{$\mathrm{P}_{3}=80 \%$} \\
\hline
\end{tabular}

Source: own work.

Commencing stage I of the project the investor incurs expenditures $I_{1}=$ PLN 1,400,000 with probability $P_{0}=100 \%$. The probability that the acquired environmental decision would be positive and stage I would be successful is $50 \%$. A positive decision only means that the investor would receive a permit to build the wind farm. The project value in that period would increase or decrease depending on the detailed provisions of the decision. Two conditions must be met to commence stage II: a positive environmental decision must be issued (probability $P_{1}=50 \%$ ), and the project value after the end of stage I must exceed expenditures $I_{2}=1,000,000$ (three of the four possible project values are positive after deducting the strike price). Therefore, option values $C_{31}, C_{32}$ and $C_{33}$ determined as above were multiplied by probability $P_{1}$. Option values for subsequent periods were determined accordingly. The project value estimated using the option method, with regard to the specific risk, amounted to PLN 1,340,296. The result indicates project profitability and constitutes a premise for its commencement.

Conclusions

The paper has discussed the economic assessment of wind farm construction in Poland, in particular the selection of methods used to benchmark the efficiency of such projects. Wind farm investment projects in Poland are characterised by the multi-stage structure of the implementation process, the presence of specific risk factors adversely affecting projects and the presence of market risk factors, whose impact on the project may be positive or negative. Investment features determine the selection of methods used for its economic assessment. On the other hand, each method exhibits properties indicating the conditions when its use may bring better results than other methods.

This paper proposed to use the real options methods for wind farm efficiency assessment. An example of an actual wind farm project in Poland was used to verify the suitability of the real options method. The selected project was first assessed using discount methods, followed by the real options method. 
The $D C F$ pricing demonstrated investment profitability ( $N P V=\mathrm{PLN} 1,696,253)$. However, after taking specific risk factors into account the project turned out to be economically inefficient $(E N P V=$ PLN $-1,134,840)$. The value of the same project estimated using the options method amounted to $C=11,036,482$. After considering specific risk it decreased to $C=$ PLN 1,340,296, however the project remained profitable. The difference in project values in the case of both methods may be explained with the non-adaptation of the $D C F$ assumptions to the nature of wind farm investment. The assumption that an investor will continue a project which is known to be generating a loss is particularly unrealistic. Of course, it cannot be said that the result gained from the $D C F$ method is erroneous, whereas the result gained from the option method correct. However, it has to be deemed that the supplementation of the economic assessment of a project made using the DCF method with the options method is legitimate. The pricing carried out using the options method will lend legitimacy to the $D C F$ result or suggest the verification of its correctness and review of the assumptions made. In both cases the application of the options method will have an advantageous impact on the investment decision.

Further studies on the applicability of the options method for the assessment of wind farm investment efficiency is of methodological, cognitive and utilitarian importance. The option approach will help to fill in the gap in assessment methods, in particular given the limitations of the $D C F$ methods discussed in the literature. The identification of analogies between the implementation of a wind farm and the purchase of options on the financial market would contribute to the extension of the scope of investment problems that may be solved using the option approach.

A practical application would enable empirical verification of the applicability of the method to solve real investment problems.

\section{References}

Bęben, R., Chmielewski, M. (2012). Elektrownie wiatrowe jako przedmiot wyceny na rynku odnawialnych źródeł energii w Polsce. Prace i Materiały Wydziału Zarzadzania Uniwersytetu Gdańskiego, 4 (1), 5-22.

Copeland, T., Antikarov, V. (2001). Real Options. A practitioner's Guide. New York: Texere. Cox, J., Ross, S., Rubinstein, M. (1979). Options Pricing: A Simplified Approach. Journal of Financial Economics, 229-263. 
Dixit, A.K., Pindyck, R.S. (1994). Investment under Uncertainty,. Princeton, New Jersey: Princeton University Press.

Frolund, S.G., Obling, P.E. (2010). Valuation Models for Wind Farms under Development, MSc thesis. Copenhagen: Copenhagen Business School.

Łukaszewski, T. (2010). Metody wyceny opcji w planowaniu przedsięwzięć informatycznych. Studia i Prace Wydziału Nauk Ekonomicznych i Zarzadzania Uniwersytetu Szczecińskiego, 20

Méndez, M., Goyanes, A., Lamothe, P. (2009). Real Options Valuation of a Wind Farm. Universia Business Review.

Mizerka, J. (2005). Opcje rzeczywiste w finansowej ocenie efektywności inwestycji. Prace habilitacyjne. Poznań: Wydawnictwo Akademii Ekonomicznej w Poznaniu.

Pesta, R. (2009). Analiza opłacalności budowy farmy wiatrowej o mocy 40 MW. Rynek Energii, 1 .

Rogowski, W. (2004). Rachunek efektywności przedsięwzięć inwestycyjnych. Kraków: Oficyna Ekonomiczna.

TPA Horwath, PAIiIZ, BSJP law firm. (2012). Energetyka wiatrowa w Polsce.

Trigeorgis, L. (1996). Real Options: Managerial Flexibility and Strategy in Resource Allocation. Cambridge, MA: The MIT Press.

Wiśniewski, T. (2008). Ocena efektywności inwestycji rzeczowych ze szczególnym uwzględnieniem ryzyka. Rozprawy $i$ Studia, 683.

Ziarkowski, R. (2004). Opcje rzeczowe oraz ich zastosowanie $w$ formułowaniu i ocenie projektów inwestycyjnych. Katowice: Wydawnictwo Akademii Ekonomicznej w Katowicach. 